\title{
Some Prehistoric Ways
}

\author{
by R. C. C. Clay, F.S.A.
}

TN Palæolithic times when each family was self-contained, before social laws and customs had bound such units together to form tribes and clans, the hunters, for such they all were, followed their quarry through the forests and along the valleys, keeping to no set trackways. They needed none, for trackways imply thoroughfares to and from fixed sites or habitations-and the Palæolithic hunter was a nomad.

When the amalgamation of families took place in early Neolithic or Epipalæolithic times, no doubt the marsh-dwellers had recognized paths across the swamps to the mainland, and those who formed the shell-mounds of Ertebolle may have used beaten paths along the shore from estuary to estuary.

With the introduction of agriculture in later Neolithic days, ${ }^{1}$ when the beaker and round-bottomed bowl were in daily use, man of necessity migrated to the more open country of the uplands. It is almost generally accepted that at this period animals were domesticated for the first time. Sheep, horses, cattle and probably pigs were bred and herded chiefly for the food their flesh produced, but to a certain extent (in the case of horses) for use as beasts of burden. Dogs were also trained to assist man in hunting. It is still an open question whether the engraved and sculptured heads, of horses dating from the Solutrean and Magdalenian periods depict bridles. The horse's head from St. Michel d'Arudy undoubtedly has one. The agricultural and pastoral life of the late Neolithic peoples implies a more settled and peaceful existence, and no doubt there was inter-tribal communication and commerce. Recognized pathways would connect settlement with settlement, and along them would be carried flint from the nearest

${ }^{1} \mathrm{Mr}$ A. Keiller has recently found at Windmill Hill, near Avebury, several saddle querns and grain rubbers associated with round-bottomed bowls. This appears to be the earliest proof of corn growing in Britain, but Kossina credits the Ertebolle peoples of Denmark with the cultivation of local grains (see Childe, Dawn of European Civilization, p. 16). 


\section{SOME PREHISTORIC WAYS}

mine. These tracks would naturally follow along the crests of the hills, not only because the valleys were undrained marshes with dense thickets, but also because the habitations to which these tracks led were themselves on the high ground. These old green roads or ridgeways have not been in continuous use. Some at least in South Wiltshire fell into decay during the Early Iron Age. For example the ridgeway that stretches from Coombe Bisset to beyond Wingreen is crossed in many places by the Celtic lynchets and cattle-ways of that period. The parallel track to the north along the range of downs that reach from Salisbury to White Sheet Hill is likewise traversed by cattle-ways that have been proved by excavation to be contemporary with the village sites of Fifield Bavant ${ }^{1}$ and Swallowcliffe Down. ${ }^{2}$ Within late historic times this latter road has been metalled and used as a coachroad until supplanted in 1758 by the modern highway along the northern foot of the hills. This ridgeway then became the thoroughfare along which drovers took huge flocks and herds to the distant markets, and many a ridgeway still bears the name of The Oxdrove. ${ }^{3}$ But now, thanks to railways and motor lorries, the old green road has once more lost its importance in the eyes of the world, and is used only by gipsies and archæologists. The author of Early British Trackways, who despises " antiquarians," would have us believe that such ridgeways were planned by some prehistoric surveyor who sighted a straight line between some church (centuries before it was built) and some round barrow. Barrows, the author states, were primarily designed as sighting points and not as burial places. His argument that roads were made because the barrows were there is putting the cart before the horse. The merest amateur in archæology knows that barrows are grave mounds, and it is necessary in archæology, as in all other sciences, to have some slight knowledge of its fundamental principles before attempting to startle the world with new theories.

The dawn of the Early Iron Age synchronized with the full development of the preceding Age of Bronze, one of the most important epochs in the prehistory of this country. At that time there were repeated and perhaps continuous immigrations of peoples along the south coast, especially in Sussex and in the neighbourhood of

1 Wilts. Arch. $\varepsilon^{\circ}$ Nat. Hist. Mag., xlii, 457.

2 Ibid. xliii, 59 .

3 The great sheep fairs at Yarnbury Castle, Weyhill and Tan Hill may owe their origin to their position on the junctions of such roads. 


\section{ANTIQUITY}

Christchurch and Weymouth $;^{1}$ the introducers of the leaf-shaped sword complex, the invaders who brought over the culture of Hallstatt, the importers of the Celtic scroll, the Belgae. Such settlers moved inland by means of peaceful penetration and hence the need of thoroughfares with a general direction of north to south. Roads of this kind would cross the prevailing east to west ranges of the south and may be termed Lateral Ways, for they linked up range to range by crossing the valleys and for the most part took a direction at right angles to the former ridgeways, although at times they themselves joined and were incorporated in the latter. These lateral ways were not new products of the period, but were old tracks through natural passes in the hills, pre-existing fords and former clearings in the wooded valleys, that were developed and came once more into more general use. If all the localized "flint sites" or camping grounds of flint using peoples in an area such as the south-western corner of Wiltshire are mapped, it will be noticed that they appear to be situated close to natural passes in the hills or opposite river crossings, and that they lie alongside tracks which, though now disused in some instances, are mentioned as lanes in the Anglo-Saxon charters and were therefore recognized thoroughfares. Moreover it will be seen that these ways, if traced for several miles, link up chains of camps. As an illustration of this the following section of road may be cited. If we start at Knighton Wood and travel northwards down the road that runs along Church Bottom we pass on the east the square earthwork called Wuduburh ${ }^{2}$ in the Saxon charters and proved by excavation to be of Early Iron Age date. ${ }^{3}$ Crossing the River Ebble at the position of the modern bridge, the road went slightly north-westwards and up the western edge of the coombe that leads to Chiselbury Camp (Early Iron Age undoubtedly; but that, as Kipling says, is another story). The road can then be traced to the east of Chiselbury into Sigwine's Dyke (sunken road), then along the foot of the hill for a short distance to reach the Green Drove, and so through the pass called Sandy Hollow over the edge of the high greensand terrace and down to Catherine's Ford over the River Nadder. The road then goes due north over the opposite greensand ridge by another Sandy Hollow with Wick Ball Camp ${ }^{5}$ on the west and past

${ }^{1}$ Antiq. Four., ii, 27 and W.A. $\mathscr{F}$ N.H.M., xliii, 3 г3.

2 Arch. Four. (1920), xxvii, 27.

3 To be published shortly in Wessex from the Air.

4 Arch. Four. (1919), xxvi, 193.

5 Very similar in design to Chiselbury. 


\section{SOME PREHISTORIC WAYS}

Dinton Beeches with Hanging Langford Camp ${ }^{2}$ (Early Iron Age) and Bilbury Rings on the east, over the River Wylye by the ford at Deptford and so past Yarnbury Castle ${ }^{2}$ (certainly Early Iron Age) past Stonehenge and Vespasian's Camp to Beacon Hill. It then divides, one branch being continued on as the Harroway through Weyhill and Hurstbourne to Farnham, the other turning south-eastwards past Quarley, Danebury $^{3}$ and Woolbury Camps to Winchester and so along the south downs of Sussex. This road with its branches from the River Wylye has been traced by Dr Williams Freeman.4

Before describing double-lynchet Ways it would be as well to define and, as far as possible, explain the mode of formation, or rather the growth of a lynchet. Lynchets are banks seen on the crests and slopes of hills, especially in chalk districts, which are arranged in a more or less regular pattern and which represent the boundaries of ancient cultivated areas. Before the work of Curwen, ${ }^{5}$ Crawford, ${ }^{8}$ and Toms ${ }^{7}$ there was very little definite knowledge on the subject of lynchets, and many of the guesses as to their purpose were not only incorrect but fatuous. It can now be accepted as an established fact that the area enclosed by lynchets was once ploughed ground, and that the natural slope of the land has been altered by that ploughing. In order to understand better the nomenclature applied to the different varieties of lynchets to be described later the method by which these areas were cultivated must be touched on now. Undoubtedly the one-way plough was employed, and furrows were driven always along and never up the slope of the ground. By the one-way plough we imply a plough with one share, probably of wood, that was driven along the slope for a distance corresponding to the length of a lynchet and then brought back empty and the process repeated. In other words ploughing was done in only one direction. It may be argued that prehistoric man would not be so stupid as to waste time in bringing back his empty plough, since the slope in the reverse direction would be as easy as in the outward.

${ }^{1} \mathrm{Mr}$ Newall's excavations have proved this site to date from La Tène III.

2 Just after the war I examined a portion of the rampart on the north side that had been damaged by a bomb and in the material forming the rampart found a large piece of pottery that is unquestionably Early Iron Age in date.

3 Crawford. Observer, 4 Oct. 1925.

4 Williams Freeman. Field Archeology (map at end of book).

5 Curwen. Sussex Arch. Coll. lxiv; also Williamson. Brighton \&' Hove Arch. ii, p. 55 .

Geographical four., lxi, 342.

7 The Antiquary, Nov. I9I I ; also Procs. Dorset N. H. \& A. Field Club, I925. 


\section{ANTIQUITY}

The answer to this is that prehistoric man did plough in one direction only and that he had a very good reason for so doing. It has already been stated that lynchets are seen on the crests and slopes of hills, and it is readily understood that at the time when these lynchets were formed, the uplands were the only suitable districts for cultivation. The valleys were undrained and consequently consisted of vast marshes interspersed with shallow pools and covered with dense vegetation. Again it is an accepted fact that prehistoric settlements with few exceptions were situated on the hills, and it is only reasonable to suppose that the inhabitants of these settlements had their cornland as close to their homes as could conveniently be. The land they cultivated was naturally sloping, and as such was unsuitable for corn growing in wet weather-we know that the climate was damper in those times-they invented the method of one-way ploughing in order to flatten the slope.

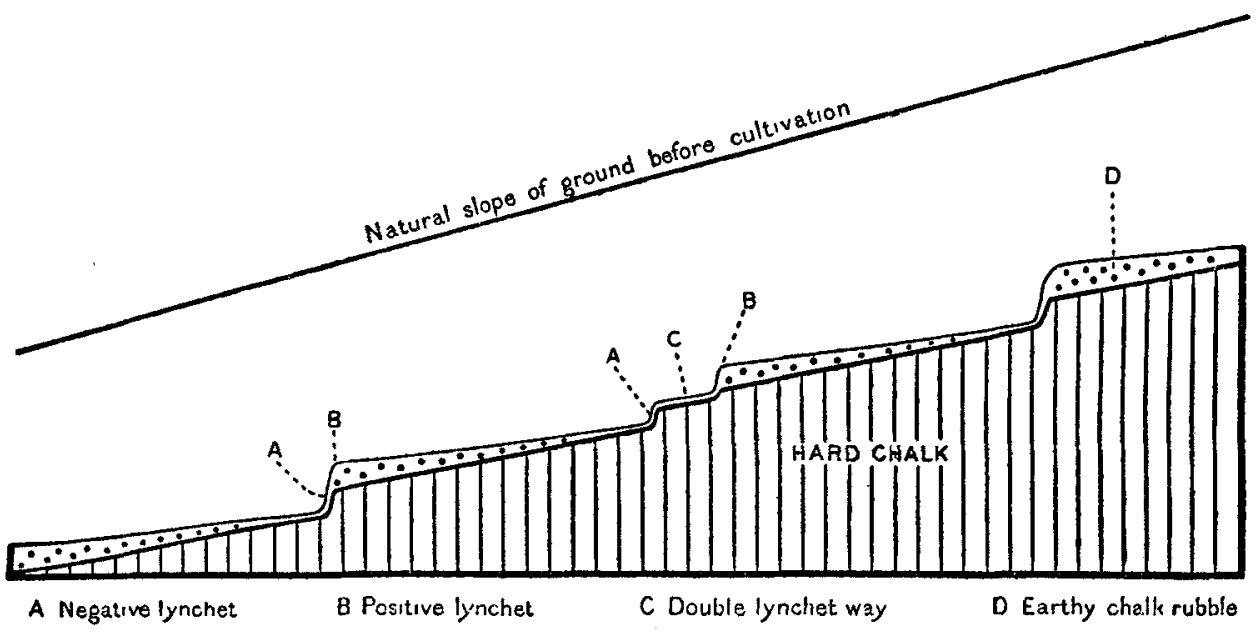

Forty years ago a farmer employed the same method to level a prehistoric vallum on Salisbury Plain. It will be seen that by ploughing in only one direction the result is that an amount of soil equal to the amount of soil in one furrow is transported from the upper side of the area ploughed to the lower. In other words the lower edge gains a furrow of soil each time it is cultivated and the upper loses it-the middle of the area changing in proportion. Thus the area tends to become less inclined, and if the ploughing was continued long enough would become quite horizontal. Turf is a great check to silting, but once the ground is cultivated there is during the season a perceptible 


\section{SOME PREHISTORIC WAYS}

amount of spreading of the soil downhill. In the same way stones would gradually collect at the bottom of the fields. They would be picked up and placed at the edge. In process of time an area of ground having been marked out and ploughed by this method the lower edge of the field would become raised and the upper cut away like a step. The former has been termed a positive and the latter a negative lynchet by $\operatorname{Dr}$ Curwen. What actually happens is that where there is a lynchet system comprising many fields, negative lynchets lie directly under positive, and the whole slope looks like a flight of steps ; the tread of the steps corresponding to the cultivated area and the edge of the steps to the top of the positive lynchet. Lateral lynchets consist of the natural unploughed ground, and run up and down the slope of the hill. They are at right angles to the positive and negative lynchets. They constitute the boundaries between adjoining fields and are prominent for the reason that the soil on either side of them has been cultivated, and therefore has somewhat silted downhill, and because they are affected by the flattening of the area they enclose. The natural vegetation on them has been unchecked, and often stones have been picked off the fields and placed on them. This all tends to increase their prominence. In districts where sarsens abound, like the Marlborough downs, lynchets for these reasons have almost the appearance of stone walls. Crawford has distinguished two types of lynchets, the Celtic or chessboard, and the strip. These names explain their shape. Those of the chessboard type are usually on the crests and slopes of hills and are earlier than those of the strip type, which are commonly found at the foot of the slopes and are Saxon in date. In the same paper Crawford points out that the Saxons broke the tradition of hill-top habitation and settled in the valleys, and the natural desire to have farmlands as near as possible to the village is strong evidence in favour of the strip lynchets at the foot of slopes being Saxon in origin. Some at any rate were cultivated down to modern times. Usually the positive and negative lynchets at the ends of fields that adjoin one another laterally, and form a more or less horizontal row divided up into rectangles by lateral lynchets, appear to make a long unbroken bank. Sometimes however when viewed in an unfavourable light so that the lateral lynchets are not seen, the system on a hillside takes the form of a group of parallel short banks placed "en échelon." This is the case when the lynchets on the western slopes of Wylye Down ${ }^{1}$ are viewed from the

1 Wilts 6-inch 0.s. 59 sw. 


\section{ANTIQUITY}

road that crosses Bapton Down. These short banks represent the positive and negative lynchets of a chess-board type of system, the lateral lynchets of which are shown up only by an unobscured setting sun. The reason that the vertical rows of fields do not exactly correspond with one another is that cultivation was begun on the west side of the winding road on top of the slope and proceeded downwards to the west, and that consequently the vertical are unequal in length.

Double-lynchet Ways ${ }^{1}$ are roads that lead either straight or with right-angled turns through the middle of systems of lynchets of the Celtic or chessboard type. They are in fact farm roads through prehistoric ploughed land, and like all farm roads often lead to village settlements. Mr Wicks and $\mathrm{Mr}$ Stoney Smith have lately cut a section through a Celtic field-way on Charmy Down, near Bath, and found deeply worn wheel ruts. The surface of a double-lynchet way is the original natural down, while it is delimited on one side by a negative lynchet and on the other or upper side by a positive lynchet. The position of the double-lynchet way in respect to the old cultivated fields determines the character of its edges, so that occasionally when it passes the positive lynchets at right angles, it is delimited by the banks that form the lateral boundaries of the fields. The age of these ways is the age of the Celtic field system which may be anything between the late Bronze Age and the end of the Roman occupation. The question may be asked "Do any of these lynchets date from the late Neolithic period when corn growing was first introduced into England ?" The answer is in the negative. In certain localities rough examples of flint picks of the Thames and Spiennes types are relatively common. There is every reason to believe that these implements were used as hoes for cultivating the ground. By cultivating is meant the loosening of the soil after the seed has been scattered over it, a method still employed by some primitive peoples. The only alteration in the natural slope of the ground due to this method would be a very slight flattening caused by the increased silting from soil that is not turf bound.

Hollow Ways or Sunken Roads ${ }^{2}$ are commonly seen running up the chalk escarpments in a slanting direction and taking advantage of the easiest gradients. They lead sometimes to camps or inhabited sites on the crest; at other times they skirt the modern roads that connect

\footnotetext{
${ }^{1}$ Curwen, Sussex Arch. Coll., Ixiv. p. 47 .

'Curwen, Brighton $\mathcal{E}^{\circ}$ Hove Arch., i, $3^{6}$; also Williams Freeman, Field Arch.,
} 


\section{SOME PREHISTORIC WAYS}

valley to valley and possibly are Saxon in origin, for Mr Crawford has shown that none of the riverside villages of Wessex can be traced back further than Saxon times. Many hollow ways lead to former arable land on top of the downs-land that was brought under cultivation during the Napoleonic wars when farming was at a premium. They are not so deeply worn as the prehistoric hollow ways for the reason that they were used for only a limited period. At times hollow ways bear a superficial resemblance to cattle ways (to be described later) when they are bounded by slight banks. These banks however are composed of the soft mud shovelled up from the surface of the road, and are related to the upkeep and not to the construction of the road. Besides, hollow ways lead in a slanting direction along the easiest gradient, whereas cattle ways run directly over the crest of a hill from valley to valley.

Cattle Ways are earthworks consisting of a ditch between two banks that usually run a perfectly straight course and connect the heads of two coombs by passing over the dividing ridge of down. To such structures Sir Richard Colt-Hoare has given the name of "Covered Ways," paper on them, ${ }^{2}$ there is still room for further investigation into the subject and for fresh theories as to their purpose. From an examination of the south-west corner of Wiltshire the following facts are brought to light. These ways are grouped within certain areas which are closely connected with Early Iron Age habitations and are not related with Romano-British villages. ${ }^{3}$ In these areas the number of cattle ways coincides with the number of opposing coombes that can be connected up ; thus they are found close together where there are numerous coombes and widely separated where coombes are scanty. The extent of an area is roughly four miles, the width of an area being the width of the downland. In any one area the width of the ways from crest to crest of banks is more or less constant, but the average of any one area may differ from that of another. The areas of down over

1 Ancient Wilts., South, p. 244.

Curwen, Sussex Arch. Coll., lix. See also Warne, Ancient Dorset, p. 25. Philips, The Rivers, Mountains and Sea Coast of Yorks., p.215. Pitt Rivers, Brit. Assoc. Report, I881, p. 69o. Greenwell, British Barrows, p. iii. Guest, Origines Celtica, ii, p. 200. Cole, Yorks. Geol. \&' Polytechnic Soc. Proc., r888, p. 45. Mortimer, Forty Years' Researches, p. 379. Kitson Clark, Proc. Soc. Antiq. Lond. xxiii, p. 309. Wilts A. and N.H.M., xxxviii, p. 69.

${ }^{3}$ For example see Wilts 6-inch 0.s. 69, NE, SE, and NW. 

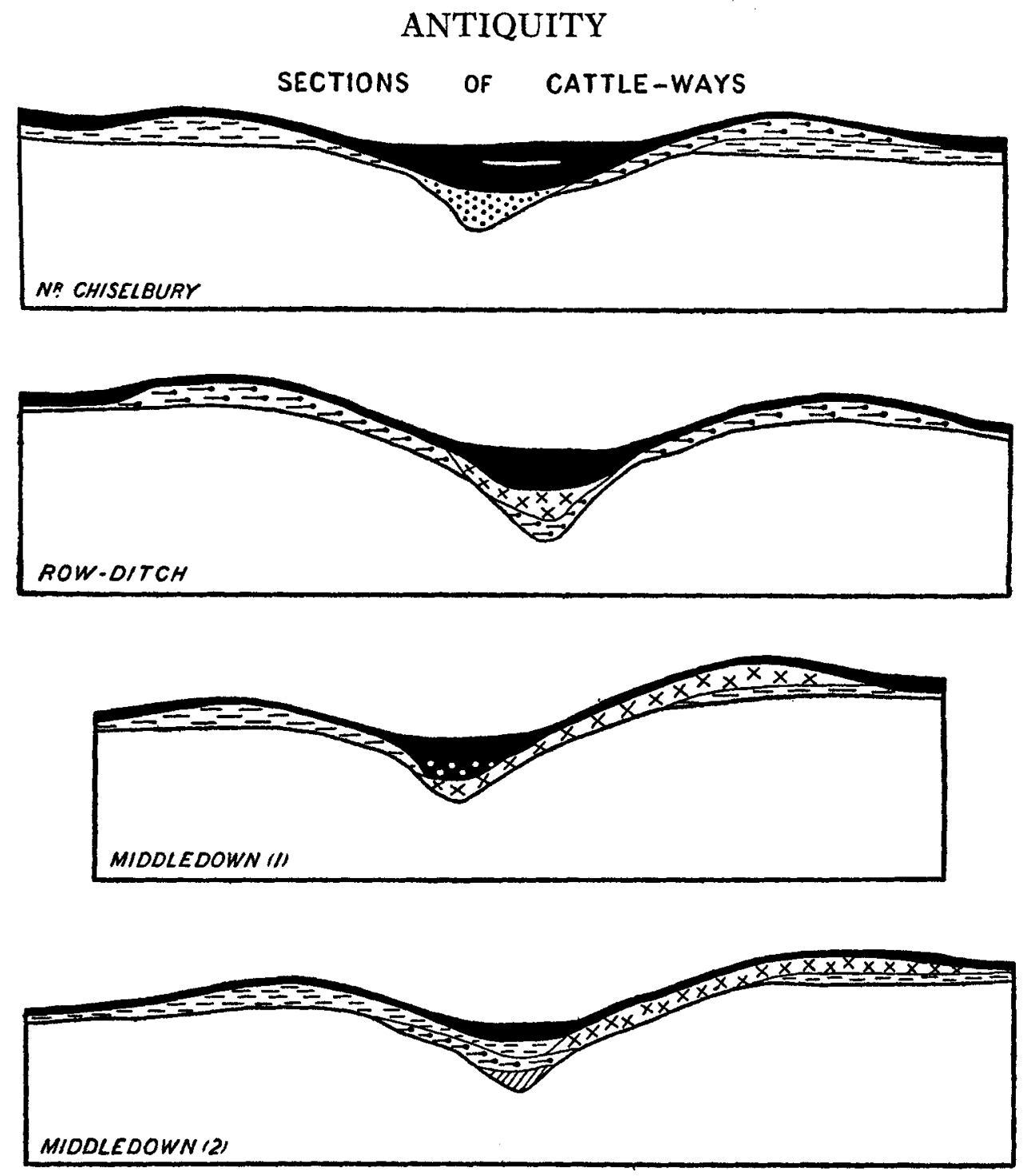

Mould
$\therefore$ Fine mould

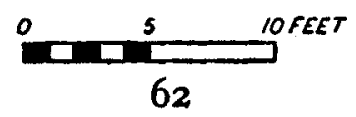




\section{SOME PREHISTORIC WAYS}

which these ways run bear surface indications that they were formerly covered by ploughlands divided up into rectangles of the Celtic or chessboard type by lynchets. These lynchets, it is also noticed, are contemporary with or later than the ways, for they run up to and end at the ramparts which are often transformed into either positive or negative lynchets.

Sections have been cut across four separate ways in an area around the Early Iron Age villages of Fifield Bavant and Swallowcliffe Down. These ways are so similar in plan and dimensions that it may be suggested that they were marked out by the same person. They all cross the ridgeway, a fact verified not only by direct observation but by aerial photography and by sounding with a heavy rammer. The cattle way running north-west and south-east across the ridgeway, 200 yards south-west of the Swallowcliffe Down village, was investigated and a section cut through it about 50 yards south of the ridgeway. There were vestiges of a lynchet system on the west side, modifying the structure and shape of the corresponding bank. The material of this bank was composed of earthy rubble with a great quantity of flints but little chalk, while the other consisted almost entirely of chalky rubble with little or no earth or flints. This indicates that the builders of the way constructed the former bank first from the top soil removed from the area intended for the ditch, and then went back to where they had started, deepened the trench and threw out the chalk they reached to form the eastern bank. The explanation is that it is easier to work up hill when digging a trench, and to shovel out the loosened soil to the left provided that the workman is right-handed. It can be presumed that these shovels were of the type commonly used in the Early Iron Age and made of the shoulder blades of oxen with the spines cut down. Dr Eliot C. Curwen has lately published an exhaustive paper on these objects. ${ }^{1}$ In the section the hard chalk was found to slope away from under the crest of the ramparts on either side, and then to fall steeply to form a narrow flat-bottomed trench about one foot in width. This floor was covered by a thin layer of very compact chalky rubble, surmounted by a stratum of flints trodden down so hard that great difficulty was experienced in excavating it. Above this the filling of the ditch was comparatively loose. A fragment of pottery undoubtedly Early Iron Age in date was discovered lying upon the trodden flint bed. Beneath the northern bank were

${ }^{3}$ Sussex Arch. Coll., lxvii, 138-45. 


\section{ANTIQUITY}

many calcined flints and fragments of sandstone, inferring the proximity of a habitation site. The mould over the trench was very deep, free from flints and chalk and slightly marly; and it is interesting to note that the grave of the primary Saxon barrow near by ${ }^{1}$ was filled with mould of a similar nature which must have come from above the cattle way. Thus the conclusion can be drawn that the latter is Early Iron Age in date and was constructed at a time when the Swallowcliffe Down village was extant.

Many suggestions have been made as to the purpose of these structures, and Dr Curwen has refuted most of them. They were certainly not defensive, for the alpha and omega of prehistoric defence was to be above your enemy and not to stand at the bottom of a narrow ditch ; besides, the making of two banks is a smaller obstacle to your enemy than one high one. Neither were they boundaries of tribal areas, for in places they were too close together. The presence of the hard trodden floors indicates that they were used as thoroughfares for men or cattle-probably the latter as their pointed hoofs would have been more likely to have caused the puddled condition. If they had been covered ways leading down to water supplies or wooded cover they would have run up to the prehistoric village with which we know they were contemporary. The writer's theory is that they were cattle ways along which Celtic men drove their herds in single file from grazing ground to grazing ground without the danger of the animals running over and damaging the crops that grew in the fields covering the high land. At the present day farmers erect a light fence on either side of the path between their cornfields before they drive their cows into that portion of their arable land which they have sown down to rotation grass of one or two years' "lay." The walls of the ditches of these cattle ways are so steep that cattle could not clamber up them, and the fact that they are so narrow is an advantage, for not only does it prevent an animal from turning round and walking back, but it also necessitates the animal's looking forward, and anyone who has had experience with cattle knows that they seldom stop and block the road unless they first turn across the direction in which they are being driven. The fact that these ways begin a few yards beyond the edge of the lynchet fields would facilitate the driving of cattle into them, all that was required would be the presence of a boy on either side of the entry. Cattle soon accustom themselves to a certain path

${ }^{1}$ W. A. \& N. H. M., xliii, 435 . 


\section{SOME PREHISTORIC WAYS}

and are in the habit of following in each others footsteps. They will also, if driven, travel directly up a steep incline and not, like human beings, follow the easiest slope.

The following species of Mollusca have been identified by $\mathrm{Mr}$ A. S. Kennard, A.L.S. and Mr B. B. Woodward, F.L.s. from material taken from the lowest level of the silting in the cattle way that runs into Chiselbury Camp :-

Limax arborum (Bouch. Chant.)

Helicella nitidula (Drap.)

Helicella radiatula (Alder.)

Arion sp.

Fruticicola hispida (Linn.)

Xerophila itala (Linn.)

Vallonia excentrica (Sterki.)

Helix nemoralis (Linn.)

Cochlicopa lubrica (Mull.)

Pupilla muscorum (Linn.)

Vertigo pygmaea (Drap.)

They state "This is a downland faunule, not of the arid type but indicating slightly damp conditions." 